\title{
What Makes up an Effective Emotional Intelligence Training Design for Teachers?
}

\author{
Niva Dolev \\ .Kinneret Academic College, Israel \\ Shosh Leshem \\ Kibbutzim Academic College of Education, \\ Technology and the Arts, Israel \\ Stellenbosch University, Stellenbosch, South Africa
}

\begin{abstract}
Recently there has been a growing interest in ways in which Emotional Intelligence (EI) can be enhanced among teachers. However, although it has been noted that effective teaching requires high levels of EI, little is known about effective methods to develop teachers' EI. The current qualitative study followed a two year EI development training for 21 teachers in one school in Israel. Main emerging themes related to the training design included the focus on teachers' own development, the combination of personal and group processes, flexibility and self direction, long-term in-school training, and leadership support. Implications for future teachers' EI training design are discussed. The findings advance our understanding of possible mechanisms for promoting high-quality EI professional development for teachers.
\end{abstract}

Keywords: Emotional intelligence (EI); Teachers' training; EI development; Coaching; EI workshops.

\section{Introduction}

During the last few decades a considerable body of research has indicated that beyond abilities and backgrounds, students' cognitive, emotional and social functioning is highly dependent on the quality of the teachers that teach them (Darling-Hammond, 2000; Muijs, 2006; van Uden, Ritzen \& Pieters, 2013; Hattie, 2015). While the importance of teachers' selection in entry level has been highlighted, high quality professional development in teachers has been considered essential for effective teaching and for school achievements (Guskey, 2002; Day et al., 2007; Darling-Hammond et al., 2009). Knowledge of content and pedagogy, class management and instruction skills are typically among the most common characteristics associated with effective teaching and are also the main target of teacher professional development (Darling-Hammond et al., 2009). However, other skills, such as reflection and communication skills; commitment, empathy, care and motivation; the ability to create positive and nurturing 
learning environments and positive student-teacher relationships have been highlighted (Kyriacou, 1998; Anderson, 2004; Stronge, 2007). Stronge et al. (2004) suggested that such qualities are characteristic of the 'teacher as a person' (p.29), while others noted that many of them are included in the concept of Emotional Intelligence (EI) (Day et al., 2007). Indeed, EI, the adaptive integration of emotion and thought (Salovey \& Mayer, 1990), and the set of related socialemotional skills and competencies (Goleman, 1995; Bar-On, 2006), has been recently suggested to be an important ingredient to effective teaching (Haskett, 2003; Drew, 2006).

Teaching is a highly emotional and social practice (Hargreaves, 2001). Thus, effective teaching and teachers' EI skills are closely related. Teachers experience a wide range of emotions (Nias, 1996) which affect teaching and class behaviours (Hargreaves 2001), social relationships with students and others (Palomera et al., 2008), teachers' well-being and personal and professional selfview (Nias, 1996). These, in turn, impact students' well-being, learning and academic success (Perry \& Ball, 2007). In order to succeed, teachers have to identify, understand and manage their own emotions as well as those of their students, who experience a similarly wide range of emotions and which impact their well-being and successes (Brackett \& Katulak, 2006). Goleman (1995) further noted that teachers play a crucial role in developing EI skills in children and helping them gain the necessary set of skills to cope with challenges, including those brought about by life in the modern era. This role requires welldeveloped EI skills and modeling emotionally intelligent behaviors (Elias et al., 1997; Brackett, 2008).

It has therefore been recommended that professional development programs for teachers should define a much broader purpose than the one commonly used, which gives prominence to academic and pedagogical knowledge (Guskey, 2002; Darling-Hammond et al., 2009). More specifically, it has been suggested that teacher trainings should include efforts to develop teachers' social emotional competence (Day et al., 2007; Palomera et al., 2008; Waajid, Garner \& Owen, 2013).

However, despite the fact that growing attention has been given to students' EI development through social emotional learning (SEL) programs (Zins et al., 2007; Rivers \& Brackett, 2011), there has been little focus on EI trainings and development of EI competencies in pre-service or in-service training programmes for teachers (Cohen \& Sandy, 2007; Jennings \& Greenberg, 2009; Waajid et al., 2013).

The current study is aimed at addressing this gap in the literature and investigates what makes up an effective EI training design for teachers. This study is the qualitative part of a comprehensive study, which followed an EI training for 21 teachers in one school in Israel for two years and looked into the impact of the training. The training included workshops and personal EI sessions for teachers, led by an external team of EI experts. The training was based on the Bar-On model of EI which includes five main scales: intrapersonal, interpersonal, adaptability, stress-management, general mood and 15 competencies within it (Bar-On, 1997). 
The training was found to increase teachers' EI levels on group and individual levels as measured by the Bar-On EQ-i, a self-report quantitative measure. Shifts were found in total group EI, from 101.57 to 105.24, and in 14 of 15 EQ-i subscales. Interviews indicated that the teachers embraced EI as highly important in educational context and to their own work, and viewed the training as highly effective and meaningful. The training had a profound perceived impact on teachers' EI levels and upon EI related behaviours. Shifts that were credited to the training were highly individual in nature and extent, and were perceived as an on-going process. Teachers further noted developing awareness to students' EI skills, and voluntarily beginning to develop their EI informally, through modeling and interactions and formally, through EI lessons. Additionally, improvements in team relations and atmosphere, and organizational efforts to formally incorporate EI in the curriculum were noted (Dolev \& Leshem, 2016).

As part of the study, the participants were asked about the elements that contributed to the training effectiveness, the focus of the present study. The insights might contribute to the design of effective teachers' EI trainings.

\section{Theoretical Background}

\section{Emotional Intelligence}

Emotional intelligence (EI) has been first introduced by Salovey and Mayer (1990) who suggested that EI relates to the effective integration of emotion and thought and described it as comprised of the ability to identify, use, understand and regulate emotions in the self and others. Defining EI more widely and discussing EI as a set of skills that manifest themselves in behaviours, Bar-On suggests that EI is 'a cross-section of interrelated emotional and social competencies skills that determine how effectively we understand and express ourselves and others and cope with daily demands (Bar-On, 2006, p. 3).

Teaching has been suggested as one of the professions in which EI plays a particularly important role (Sutton \&Wheatley, 2003; Drew, 2006; McCown et al., 2007; Myint and Aung, 2016). EI has been linked to different aspects of school life, such as students' pro-social behaviours (Brackett et al., 2004), interactions with teachers and peers, learning and academic achievements (Elias et al., 1997; Zins et al., 2004; Brackett et al., 2007; Eccles, Devis-Rozental, \& Mayer, 2016). For example, Haskett (2003) found EI competencies, and in particular the General Mood scale of the EQ-i to correlate with effective teaching, comparing 86 Teaching Award recipients with 200 randomly selected non-winners. Similarly, Hwang (2007) found teaching effectiveness to be positively associated with overall EI, as well as with a number of specific competencies, including empathy, self-esteem and leadership. Furthermore, teachers' EI levels play an important role in developing children's EI (Jennings \& Greenberg, 2009) through formal teaching, modeling EI behaviours and building secure attachments (Ulloa, Evans \& Jones, 2016).

Yet, while the role of EI and its contribution to teachers' effectiveness has been recently highlighted, concern has often been voiced over the lack of data regarding the emotional and social characteristics that underlie teachers' effectiveness and the paucity of efforts to develop them in teachers (Haskett, 
2003).

\section{Developing EI Skills}

A growing body of research indicates that successful EI development efforts can enhance EI levels (Bar-On, 2006; Lennick 2007; Cohen-Katz et al., 2016; Herpertz, Schütz, \& Nezlek, 2016), and result in increase in personal and professional effectiveness (Cherniss \& Goleman, 2001; Abraham, 2005; Clarke, 2010). For example, Slaski and Cartwright (2003) found significant improvements in the mean total EQ-i (from 95.6 to 100.8) and in the general health and well-being of group members. Significant gains in EI increases in total EQ-i score (from 94 to 100) and improved financial outcomes were also found in studies of the American Express Financial Advisors EI-training programme (Lennick, 2007).

It has been argued that the development of EI in teachers could benefit teachers too; enable them to better understand what underlies their motivations and behaviours (Haskett, 2003), enhance less-developed competencies (Kaufhold \& Johnson, 2005), develop greater understanding of students' emotions (AbiSamraSalem, 2010), improve teacher-student relationships (Jennings \& Greenberg, 2009) and promote effective teaching (Cohen, 2001).

Teachers' EI trainings however are much less common than in other settings and have not been widely studied (Brackett et al. 2009; Corcoran and Tormey, 2010). This lacuna is also reflected in discussions of teachers' qualities. Trainings for teachers typically take part within an SEL program and focus on providing knowledge on EI and methods to deliver EI programs to students, rather than on teachers own EI development.

The limited number of existing efforts did show promising results, indicating the ability to develop EI in teachers (Dolev \& Leshem, 2016; Ulloa, Evans \& Jones, 2016). Such efforts have led to increased teachers' recognition of the importance of EI to schools (Maree \& Mokhuane, 2007; Dolev \& Leshem, 2016). It also enhanced teachers' sensitivity to students' emotions in different situations and increased their ability to respond constructively to students' socialemotional needs (Brackett et al., 2009).

\section{Characteristics of Effective EI Development}

With mounting evidence that certain EI training programs can increase EI, it has become important to identify the characteristics which make EI development most effective (Cherniss et al., 1998). Firstly, scholars have noted that as EI relates to personal abilities or skills, effective EI development involves not only providing a theoretical basis and an understanding of the concept, but also the development of EI competencies and changes in habits, attitudes and behaviors (Bharwaney, 2007; Boyatzis, 2007; Neale et al., 2009).

Cherniss et al (1998) further identified a number of main characteristics related to effective EI training in organizations. Those included, gaining organizational and leadership support, voluntary and self-motivated participation, adjustment of the participants' expectations and needs, and self-directed processes. These were noted to contribute to motivation and encourage participants to be personally accountable for their progress and take an active part in it (Cherniss 
\& Goleman, 2001; Boyatzis, 2007; White, 2006). Process-integrated personal EI assessments and feedback allow individuals to recognize areas of strength and serve as a foundation and motivation for subsequent development processes (Cherniss et al., 1998; Bharwaney, 2007; Hughes \& Terrell, 2009).

The use of varied, active and experiential training strategies creates and maintains interest and caters for different learning styles. Providing opportunities to practice newly acquired skills through repeated exercises and feedback sessions in different settings, would enable developing skills and establishing new behaviors (Cherniss \& Goleman, 2001; Bryan, 2006). It has been further acknowledged that EI development requires an extensive, routinized, long-term effort, which provides time for the above mentioned exploration, development, practice and repetition (Neale et al., 2009), including in teachers EI training (Brackett et al., 2009).

EI trainings can be conducted in groups or individually. EI group-based training is the most common type of training.

Beyond its cost effectiveness, the group element has been noted to address the interdependence between learners and their environments (Dasho et al., 2001); to facilitate peer support (Cherniss et al., 1998; Boyatzis, 2007); to provide real-world training opportunities; to help solve social problems within the group (Caruso and Wolfe, 2001); and to enhance collegiality and collaboration (Cherniss \& Goleman, 2001; Cohen \& Sandy, 2007). Furthermore, relationships within the group in EI development processes were noted to provide participants with context, guidance, permission to change and to develop group norms (Druskat \& Wolff, 2001).

In particular, relationships with colleagues during teacher training were argued to promote collaborative inquiry (Zins et al., 1997), and to allow for the sharing of ideas and peer-learning (Anderson, 2004). Moreover, group work among teachers within students' social emotional learning (SEL) programmes was noted to provide a sense of ownership over processes and to create a sense of synergy (Haynes, 2007), which contributes to learning and to personal development processes in teachers (Richardson, 1998; Hargreaves, 2005).

At the same time, efforts to develop EI in a one-on-one process are becoming more available, mainly with leaders. Those are often relying on the practice of coaching (Chapman, 2005). EI coaching is an individual-based training specifically designed to help individuals develop their EI skills so that they can become more effective and incorporate the theoretical and empirical aspects of EI and of effective EI development with coaching tools (Bharwaney, 2007). Typical EI coaching processes encourage individuals to select EI skills and competencies that require development (Hughes \& Terrell, 2009), often utilizing an EI assessment tool (Orme \& Cannon, 2000), and to define personal and professional goals that these enhanced competencies can help achieve (Peterson, 1996; Bharwaney, 2007).

The one-on-one setting allows to focus on individual EI competencies, unique circumstances, strengths and challenges, vision and goals (Robertson, 2004), to adjust learning styles to the learner, and to provide a safe, supportive, 
intimate and private arena for development (Chapman, 2005). One-on-one coaching has been found suitable for teachers as it allows them to understand themselves, enhance accountability and self-efficacy and to achieve personal goals (Broun, 2007).

The combination of one on one coaching with group-based training has recently been recommended as an effective EI-development tool (Hughes \& Terrell, 2009; Neale et al., 2009). Brackett et al. (2009) similarly suggested that incorporating a few personal coaching sessions in group EI training for teachers can be beneficial.

\section{Methodology}

The study followed an EI training which took place in one secondary school in Israel. Based on the interpretive view of reality, qualitative research frameworks allowed the researchers close proximity to the participants' experiences within the training in its natural setting and facilitated the accumulation of thick and rich descriptions (Geertz, 1973). The study, which was part of a larger study on the impact of the training, employed in-depth semi-structured interviews with all 21 training participants, 4 males and 17 females, age 33-64, all active teachers in the school.

\section{The Research Setting}

The setting of the research is a secondary school in northern Israel which was the only school in the country undertaking an extensive EI training. At the time of the study the school had approximately 600 students, age 13-18, and a staff of 70 full-time teachers. It is typified by a heterogeneous population, comprising students from both rural and urban settlements, different home environments and of different ethnicities and economic status.

\section{The Training}

The EI training programme was initiated by the school's head-master and introduced to staff as part of the schools continual professional development programmes. Participation was voluntary and open to all teachers but management and position holders comprised a big number of the participants. All the participants went through the same elements of training and in the same sequence.

The training, which lasted two years, was based on the Bar-On model of EI. The first year comprised a series of twelve interactive group workshops, conducted at the school after school hours and on holidays. Each workshop lasted from a few hours to a full day and punctuated by intervals of typically one month. The second year consisted of 10 individual coaching sessions, in 2-3 weeks intervals, accompanied by additional (less frequent) group workshops. Group workshops focused on EI's theoretical and empirical foundations; its relevance to effectiveness among individuals, teachers, students and schools; and on each of Bar-On's 15 EI competencies. The competencies targeted for development included self-awareness, self-regard, assertiveness, selfactualization, empathy, social responsibility, interpersonal relation, reality testing, problem solving, stress tolerance, happiness and optimism. The workshops used varied methods and facilitated activities which were conducted with the entire group of participants, in smaller sub-groups, in pairs and in individual reflective exercise. Within the coaching sessions each participant 
could develop personal EI competencies and setting personal and professional goals. Coaching sessions focused on self introspection and awareness, identifying areas that will be a focus of development and working toward their development using different methods such as introspective questions, reflecting on past experiences and identifying a vision and goals.

During the first introductory group session, a pre-training EQ-i assessment was carried out, as part of the comprehensive study. It was followed by a personal feedback session for each participant, in which the EI profile was presented and discussed. These profiles later served a developmental tool in the workshops and coaching sessions. Additionally, a group profile was presented and interpreted to the entire group and served as a base for the work in the group and the design of some of the workshops.

\section{Research Procedures}

Once the training ended, a general consent from the headmaster and all the training participants was obtained. Individual interviews were then conducted with each of the participants at a time and location of their convenience. All interviews were approximately one and a half hour long and conducted within a single, one-month period. Interviews were recorded in shorthand and transcribed prior to their analysis following the request of some of the participants. It has been made clear that participation in the research was entirely voluntary, and that the participants can withdraw at any time or refrain from answering certain questions. Participants were assured that all identifying information will be kept confidential. Interview questions were formulated on theoretical ground and incuded questions such as: can you describe the training design? How did the training elements impacted the training and its outcomes? What elements of the training were most (least) effective?

\section{Data analysis}

Interview analysis was carried out with the aid of qualitative software (Atlas-Ti 6). A thematic content analysis approach was used to analyse the transcripts (Weber, 1990). Each interview transcript was analysed and coded separately, using open coding to identify emerging themes. Cross interview categories were then constructed and codes were again compared in order to ensure that items were properly sorted and coded (Strauss and Corbin, 1990). Major categories (themes) were then identified, allowing for clusters of codes within a conceptual category to converge into 'clusters of meaning', a key step according to Creswell (1998).

\section{Results}

The study was aimed at identifying the contribution of different elements to the training effectiveness. The thematic analysis revealed a number of main themes regarding the design of the training: a teachers' centered training, personal and group processes, a long-term process, a self-directed process, a holistic approach, personal EI assessment, and management support.

Teacher centered training: Participants attributed importance to putting teachers at the centre of training, and focusing on their own development, a focus which was described as unique in their experience of teacher trainings. They frequently described the training as individual, personal and internal, a 
'personal gain' (IE) or 'a personal gift' (ISH) designed '...for each of us to gain selfknowledge and self-understanding...' (OR). Personal development of teachers' EI was viewed by the participants as essential to their professional effectiveness and to a change in the school:' The first step towards a meaningful change in schools'(OR); It had further enhanced their motivation to 'pay foreword' their experiences to students and develop their EI voluntarily, in class and other interactions, contributed to their ability to demonstrate EI-related behaviours and to walk the talk and enhanced their ability to teach EI authentically. Many also discussed the personal focus as creating a feeling of being valued, appreciated and invested in, which enhanced their motivation within the training, and their commitment to the school and to EI implementation.

Personal and group processes: The participants described the training as consisting of group workshops and individual coaching sessions. Both elements were perceived as central to the programme, and were equally valued by participants. Participants noted that the two training elements had served both distinct and overlapping purposes, found them to be complementary, and in synergy with each other. Most participants also recommended for both elements to be included in future teachers' training programmes more generally. The participants later employed both personal coaching and group workshops as part of their training sustainability efforts (for the current group and other teachers) and in the EI-training pilot programme for the students.

Group workshops: The participants noted that group workshops, which were offered throughout the training, provided them with personal and group learning and development opportunities, as well as allowed for changes in the team and in the school as a whole.

The participants noted that group workshops provided them with a large body of EI-related knowledge, promoted awareness and acceptance of EI among the participants and developed both personal and shared understanding of the concept, to which many were unfamiliar: 'It [the EI training programme] addressed a topic which is most important and relevant to education' (USH). EI provided a useful, comprehensive and practical framework for understanding and developing themselves and others, and in particular students: [EI] competencies, they sharpen your view and help you to sort things properly: What underlies different behaviours and outcomes, how to interpret certain behaviours. It [EI] offers a theory in place of intuition, and it is focused and structured' (OY).

The workshops further provided participants with opportunities to engage in EI on a personal level through self-exploration and reflection: 'For me it all [introspection] started during the workshops, when the trainers asked us what it is that we would like people to say about us when we retire... it got me thinking...' (TE).

Likewise, within the workshops, many participants actively shared feelings, experiences and insights, including those from their personal profiles, with the group and engaged in self-disclosure. This process allowed the participants to learn from their colleagues, to see themselves through their colleagues' eyes, and to receive feedbacks regarding their own insights and EI skills: 'Whenever someone would raise a topic that was related to my own experiences [I was able to] learn and understand something new about myself' (MS). "Only then, when 
teachers told me, I realised that I offend people, that my cynicism that I viewed as social, is really offensive (IE). Sharing difficulties and emotions regarding EI development helped participants not to feel alone in the journey and to deal and overcome them through shared experiences and support: "'it helped to know that other people are going through similar things" (GY).

Group workshops were also the setting in which the impact of the training was extended beyond the individual domains to the team and the organisational (school) domains. Participants credited the group processes within the workshops with creating cooperation and collaboration among the participants, fostering new group norms and dynamics and improved inter-team relationships: 'We started to view teachers differently... to understand things differently... We started appreciating things that we had not paid attention to before (LI). Participants allowed themselves to become vulnerable and began talking about difficulties at work and seeking advice and help: 'People weren't afraid to talk about themselves or to expose weaknesses... People felt safe enough to share failures and to ask for help...(WN): 'There is more collaboration. You are not alone anymore. People no longer keep their knowledge to themselves... (VA), 'You feel that people are really together, that they want to help each other. [There's a feeling of] real partnership' (BP).

The group discussions led to changes in the school, resulting in an initiation and implementation of an EI program for students while still in training. The participants spoke with much pride of their implementation effort, referred to them as 'our programme' and put much time and effort in designing and executing it. These broader impacts were accomplished through group learning and discussions of pedagogic ideas: 'It was us who had undergone the training, and now we were passing the knowledge on, in all kinds of ways, to the students, because we are actually one - teachers and students' (OR).

Personal coaching: Personal coaching was described as a self-directed process in which the participants received guidance and on-going support while becoming involved in a personal development process. While self-exploration and development began for many at the workshops, a majority viewed coaching sessions as essential for their EI development, providing a more in-depth and individual introspection and personal development. For some, self-exploration only began in personal coaching. Within the coaching sessions the participants enhanced their self-discovery and personal insights, identified and selected the competencies, behaviours and habits they most wanted to explore and develop; defined a vision and proceeded to develop the selected competencies: 'You (sic) would discuss certain topics with your trainer, and [consequently] you would see everything in a new light... things would become clearer....' (GN). :'I would not have identified many of the issues [that I had to address] myself [without my coach]. Even the personal segment of the [group] workshops was not enough' (BP).

Coaches were noted to provide a safe, supportive and challenging atmosphere: 'I discussed many things that I had not discussed before... I was able to be me...lowered my defences. There aren't many people who I trust to that extent' (VA). "I could pour my heart, open up and discuss sensitive issues... I was able to take risks' (RI). Support was particularly important to the participants as for many selfexploration was an emotional and sometimes difficult process. They often referred to the coaches as figures who are '...there just for you' (FE), or 'who care 
about you' (OY) which was seen as novelty within teacher trainings and a personal gain.

While many participants noted the privacy of the coaching sessions and the insights offered by coaches as essential to their progress, some assigned much importance to the ability to share experiences with the group.

A long term process: Rather than perceiving it to be a burden, the relatively long, two-year duration of the training programme was valued by all participants: 'Schools usually don't have time or patience. They are in a hurry. Therefore changes [in schools] are usually external and superficial' (OR). It allowed them to engage in deep introspection to develop each at their own pace, thus affecting a 'real change' (GY), to come together as a group, to explore ways to bring EI to their classes, and to design and implement school changes. At the same time, despite the lengthy duration of the programme under study, efforts to engage non-participant teachers in EI during its course had hardly been noted, leading, according to some participants, a relatively limited impact of the training upon the students and the school and feelings of exclusion among some non-participant teachers.

A self-directed process: Many participants drew attention to the flexible and dynamic nature of the training programme, in all its stages and domains. They said it was tailored to their individual 'starting points' as well as to the pretraining conditions in the school in which it took place. They appreciated the autonomy to follow directions most suitable for them, to deal with new-found challenges, to integrate new insights into their personal and professional development process, and thus to take part in designing and guiding this process. However, such flexibility did not come without a price and participants did note instances in which the programme strained to adapt to emerging needs. For example, some participants regretted the lack of SEL-related reading materials (SEL not being a direct goal of the training programme).

A holistic approach: Participants explored competencies and behaviours, values, perceptions, habits and aspirations in a variety of settings. The programme supported exploration of both personal and professional themes, in school and out, and thus allowed for different sources of motivation, such as the desire to achieve personal growth, to increase effectiveness at work and to develop EI in others. These, in turn, provided a variety of ways for EI to 'permeate' the school, and turned the concept of EI into a 'life view': 'Even newspapers, I now read them differently, I see in them things that I haven't seen before... I now often bring newspaper articles with me to class, I highlight events that have to do with $\left.E I^{\prime}(B P)\right)$.

Personal EI Assessment: A majority of the participants noted that their personal EI profiles (using the EQ-i) provided them with valuable information about themselves and were central for their development and the effectiveness of the training 'The assessments ... benefited each of us personally. I was able to get a 'scientific proof' of what I knew about myself, and to learn new and surprising things about myself' (OY).

The profiles increased awareness to personal EI skills, motivated the participants to engage in a more thorough exploration of their EI and to understand the manner by which EI competencies manifest themselves in their behaviours and impact their lives and work. This, in turn, laid the foundation for 
a later process of looking at other people, mainly students, through the same lens, as noted by one of the participants: 'Once we saw ourselves differently we were able to see our students differently, everything became clearer...' (BP). The profiles were also found to evoke deep emotions in participants who found their EI lower than they expected or were faced with specific lower skills: I was in a state of great uncertainty and confusion... It [the feedback] touched upon my self-esteem and affected my image as a teacher and as an educator... It was really hard to go through this process but worthwhile' (MS). For the majority of them, such emotions were temporary and did not discourage them. Two veteran teachers, however, decided not to engage in active personal development but rather on students' development.

Management role: a number of participants referred to the important contribution of the commitment of the school management to the programme, the financial, administrative and professional support and in particular, their support for various initiatives, including the pursuit of career transitions in search of more fulfilling roles.

Beyond it, management staff members were noted to participate in all stages of the training as equal partners. They openly discussed personal weaknesses, shared personal experiences with other participants during group workshops, attended personal coaching sessions, and took an active part in coaching students and in teaching EI.

\section{Conclusion}

During the last two decades a growing body of research suggests that social-emotional skills are linked with the abilities to cope effectively with life challenges and to succeed in a variety of vocations (Parker et al., 2009), including teaching (Sutton \& Wheatley 2003; Maree and Mokhuane 2007; McCown et al., 2007). This creates the question of how to design effective EI trainings for teachers, of high importance. However, only a few training programmes have attended to the emotional competence of teachers (Cohen \& Sandy, 2007; Jennings \& Greenberg, 2009; Corcoran \& Tormey, 2010). Thus, not much is known about effective EI training design for teachers.

The current study followed an EI training for teachers within a school. It revealed the specific training elements which contribute to a useful framework for EI development in a school setting, as well as areas for further improvement. Firstly, the present findings indicate that a focus on teachers within EI training contributed to many of the outcomes of the training program under study, including the participants' favorable view of the EI training; their high motivation to engage in the training and their proactive initiatives to further EI learning in their school. It has been noted that as EI is an individual capacity in nature, EI development requires a focus on individual skills (Cherniss et al., 1998). Others emphasized the need for teachers' professional development to be one which focuses on teachers' personal development (Richardson, 1998; Friedman \& Philip, 2004). Recently, the need to focus on developing social and emotional skills in teachers (Brackett et al., 2009), and in particular experienced teachers (Corcoran \& Tormai, 2010) has been discussed. The findings echo Cherniss et al. (1998) and White (2006) who noted that motivation to become 
engaged in development is higher when perceived as promising personal, rather than only organizational gains.

The flexibility and self-direction inherent in the teachers' focus of the training allowed for a dynamic and evolving process which suits personal and school needs, supporting Boyatzis (2007) claim that self-direction is crucial within EI development efforts. Indeed, while participants were introduced to the program in the same manner, they each joined at their own starting point, chose whether and to what extent to be engaged in self-exploration, focused on different skills, chose different paths and developed in their own pace and on different levels. The self-directed nature of the training exceeded to the group level and the participants designed the EI development program for students themselves in a facilitated process. Focusing on areas which are personally and professionally relevant to the teachers enhanced motivation, engagement and accountability.

Group workshops and personal coaching were found to be central to the training. They were described as useful in embracing EI, developing personal EI skills, accounting for different learning and development styles, and motivating teachers to voluntarily develop students' EI, informally and formally. These current findings support the emerging body of recent literature in which the incorporation of individual development and group work has been recommended (Chapman, 2005; Bharwaney, 2007; McKee et al., 2009).

In the present study, EI coaching and group workshops appeared to mirror two types of efforts which are common to schools worldwide, respectively: the often-noted individual efforts in classrooms, where personal effectiveness largely affects students' success (McKinsey report 2007); and the many collaborative efforts which teachers engage in as they strive to reach shared pedagogic goals (Fullan, 1993), including those related to developing students' social emotional skills.

The one-on-one work within personal coaching in this study allowed addressing each teacher's unique set of personal behavior-related EI skills. Such a method is not typical to school training programs (Griffiths, 2005), and many training programs provide all teachers with the exact same training and consistently fail to recognize differences among teachers and to address their personal needs (Anderson, 2004).

Furthermore, in view of the complex and multi-dimensional nature of EI development (Cherniss et al., 1998; Weare \& Gray, 2003), and the inherent difficulty in identifying and changing teachers' self-behaviours (Argyris, 2000), personal EI coaching was found in this study to support self-discovery and encourage the development of personal skills. Indeed, and in line with Lasky (2005), teachers in the present study were more likely to risk vulnerability during the change process when they felt safe and believed that these changes would lead to personal or professional gains.

At the same time, Richardson (1998) has warned that failure to address group processes in teachers' trainings may lead to incoherence in pedagogical views and hence may negatively impact upon students. The school-located 
group-based workshops allowed for emotional and social processes within the group, the fostering of new group norms and dynamics, and group discussions of pedagogic ideas which led to shared views and to the design and implementation of organizational change. These findings support earlier claims regarding the contribution of group work to learning and personal development (Anderson 2004; Hargreaves, 2005), and to the enhancement of emotionally intelligent group norms (Druskat \& Wolff, 2001).

The use of a personal assessment within the training was found to be an important tool in the development of personal skills, extending Cherniss et al. (1998) insights to teachers, providing valuable insights, promoting selfunderstanding and creating a sense of urgency.

The long term effort was found to allow personal and group processes to take place. This was in line with effective CPD programmes guidelines which were recommended to be long term (TDA, 2008), and in view of the work and effort required for an EI development process (Cherniss et al., 1998). Grant (2007) highlighted the importance of intervals as an integral part of long-term training processes rather than a short-term (two days), block intensive programme. This suited the view of the participants of EI development as an ongoing process, and allowed for real life practice and reflections. However, the impact of investing in one group of teachers within a school setting for a long time period should be examined.

\section{Limitations of the study}

The study has a number of limitations: examining a single program in one school, relying on a small sample, limited to personal interviews using teachers' views only. Moreover, while various scholars have noted that training programmes should lead to sustainable outcomes (Boyatzis, 2007), the present inquiry ended soon after the completion of the EI development programme under study, not allowing examining sustainable impacts. However, the findings have an important contribution as they highlight elements which contribute to the ability to develop teachers EI skills.

Studies could examine the elements of the training design and their effectiveness in other settings and help determine and optimise a variety of programme parameters, such as the optimal length of EI training programmes for teachers, or the effects of voluntary versus compulsory participation in such programmes. More generally, studies of other types of EI training programmes could help identify the most effective way to develop EI in teachers.

\section{References}

AbiSamra Salem, N. (2010). Emotions and emotional intelligence (EQ) in curriculum theory: On incorporating EQ skills in teacher education (presentation). Presented at the31st Annual Bergamo Conference on Curriculum Theory and Classroom Practice. 16 October, Bergamo, Italy.

Abraham, R. (2005). Emotional intelligence in the workplace: A review and synthesis. In R. Schulze, and R.D. Roberts (eds.), Emotional Intelligence: An International Handbook (pp. 255-270). Gottingen: Hogrefe \& Huber. 
Anderson, L.W. (2004). Increasing Teacher Effectiveness (2nd Ed.). Paris: UNESCO, International Institute for Educational Planning.

Argyris, C. (2000). The relevance of actionable knowledge for breaking the code. In M. Beer and N. Nohria (eds.), Breaking the Code of Change (pp 415-428). Boston, MA: Harvard Business School Press,

Bar-On, R. (1997). The Emotional Quotient Inventory (EQ-i): Technical Manual. Toronto: Multi-Health Systems.

Bar-On, R. (2006). The Bar-On model of Emotional-Social Intelligence (ESI), Psicothema, 18(sup), 13-25.

Bharwaney, G. (2007). Coaching executives to enhance emotional intelligence and increase productivity. In R. Bar-On, J.G. Maree and M.J. Elias (eds.), Educating People to Be Emotionally Intelligent (pp. 183-198). Westport, CT: Praeger,.

Boyatzis, R.E. (2007). Developing emotional intelligence through coaching for leadership, professional and occupational excellence. In R. Bar-On, J.G. Maree and M.J. Elias (eds.), Educating People to Be Emotionally Intelligent (pp. 155-168). Westport, CT: Praeger.

Brackett, M. A. (2008). Emotional intelligence as a basic competency in pre-service teacher training: Some evidence. Electronic Journal of Research in Educational Psychology, 15 (6) 2, 437-454.

Brackett, M.A., Alster, B., Wolfe, C.J., Katulak, N.A. \& Fale, E. (2007). Creating an emotionally intelligent school district: A skill-based approach. In R. Bar-On, J.G. Maree and M.J. Elias (eds.), Educating People to Be Emotionally Intelligent (pp.123138). Westport, CT: Praeger.

Brackett, M.A. \& Katulak, N.A. (2006). Emotional intelligence in the classroom: A skillbased training for teachers and students. In J. Ciarrochi and J.D. Mayer (eds.), Improving Emotional Intelligence: A Practitioner's Guide (pp. 1-27). New York, NY: Psychology Press.

Brackett, M.A., Mayer, J.D. \& Warner, R.M. (2004). Emotional intelligence and its relation to everyday behaviour. Personality and Individual Difference, 36, 1387-1402. doi:10.1016/S0191-8869(03)00236-8

Brackett, M.A., Patti, J., Stern, R., Rivers, S.E., Elbertson, N.A., Chisholm, C. \& Salovey, P. (2009). A sustainable, skill-based approach to building emotionally literate schools. In M. Hughes, H.L. Thompson \& J.B. Terrell (eds.), Handbook for Developing Emotional and Social Intelligence: Best Practices, Case Studies, and Strategies (pp. 329-358). San Francisco, CA: Pfeiffer, pp. 329-358.

Brackett, M. A., Rivers, S. E. \& Salovey, P. (2011). Emotional Intelligence: Implications for Personal, Social, Academic, and Workplace Success. Social and Personality Psychology Compass, 5(1), 88-103. 10.1111/j.1751-9004.2010.00334.x

Bryan, S.P. (2006). Emotional intelligence and intrapersonal conversations. E-journal: Issues and Recent Developments in Emotional Intelligence, Consortium for Research on Emotional Intelligence in Organizations. Retrieved from http://www.eiconcortium.org/e_journal/e_journal.html

Caruso, D.R. \& Wolfe, C.J. (2001). Emotional intelligence in the workplace. In J. Ciarrochi, J.P. Forgas and J.D. Mayer (eds.), Emotional Intelligence in Everyday Life: A Scientific Inquiry (pp. 150-167). Lillington, NC: Psychology Press.

Chapman, M. (2005). Emotional intelligence and coaching: An exploratory study. In M. Cavanagh, A.M. Grant \& T. Kemp (eds.), Evidence-Based Coaching, Volume 1: Theory, Research and Practice from the Behavioural Sciences (pp.183-192). Bowen Hills, Queensland: Australian Academic Press.

Cherniss, C. \& Goleman, D. (2001). Training for emotional intelligence: A model. In C. Cherniss, \& and D. Goleman (eds.), The Emotionally Intelligent Workplace: How to 
Select for, Measure, and Improve Emotional Intelligence in Individuals, Groups and Organizations (pp.209-233). San Francisco, CA: Jossey-Bass.

Cherniss, C., Goleman, D., Emmerling, R., Cowan, K. \& Adler, M. (1998). Bringing emotional intelligence into the workplace: A technical report. The Consortium for Research on Emotional Intelligence in Organizations. Retrieved from http://www.eiconsortium.org/pdf/technical_report.pdf

Clarke, N. (2010).The impact of a training programme designed to target emotional intelligence abilities in project managers. International Journal of Project Management, 28 (5), 461-468. https://doi.org/10.1016/j.ijproman.2009.08.004

Cohen, J. (2001). Social and emotional education: Core concepts and practices. In J. Cohen (ed.), Caring Classrooms/Intelligent Schools: The Social Emotional Education of Young Children (pp. 3-29). New York, NY: Teachers College Press.

Cohen, J. \& Sandy S. (2007). The social, emotional and academic education of children: Theories, goals, methods and assessments. In R. Bar-On, J.G. Maree \& M.J. Elias (eds.), Educating People to Be Emotionally Intelligent (pp. 63-78). Westport, CT: Praeger.

Cohen-Katz, J. Sternlieb, J. L. Hansen, S. E., \&. Dostal, J. A. (2016). Developing Emotional Intelligence in the Clinical Learning Environment: A Case Study in Cultural Transformation. Journal of Graduate Medical Education, 8 (5), 692-698. https:// doi.org/10.4300/JGME-D-15-00548.1

Corcoran, R. \& Tormey, R. (2010). Teacher education, emotional competencies and development education. Procedia Social and Behavioral Sciences, 2, 2448-2457. https://doi.org/10.1016/j.sbspro.2010.03.352

Creswell, J.W. (1998). Qualitative Inquiry and Research Design: Choosing Among Five Traditions. London: Sage.

Dasho, S., Lewis, C. \& Watson, M. (2001). Fostering emotional intelligence in the classroom and school: Strategies from the Child Development Project. In J. Cohen, (ed.), Caring Classrooms/Intelligent Schools: The Social Emotional Education of Young Children (pp. 87-107). New York, NY: Teachers College Press.

Darling-Hammond, L. (2000).Teacher quality and student achievement: A review of state policy evidence. Education Policy Analysis Archive, 8 (1), pp. 1-44.

Darling-Hammond, L., Chung Wei, R., Andree, A., Richardson, N. \& Orphanos, S. (2009). Professional Learning in the Learning Profession: A Status Report on Teacher Development in the United States and Abroad. US, National Staff Development

Day, C., Sammons, P., Stobard, G., Kington, A. \& Gu, Q. (2007). Teachers Matter: Connecting Lives, Work and Effectiveness. Berkshire: Open University Press.

Dolev, N. \& Leshem, S. (2016). Teachers' emotional intelligence: The impact of training. The International Journal of Emotional Education, 8(1), pp. 75-94.

Druskat, V.U. \& Wolff, S.B. (2001). Group emotional intelligence and its influence on group effectiveness. In C. Cherniss \& D. Goleman (eds.), The Emotionally Intelligent Workplace: How to Select for, Measure, and Improve Emotional Intelligence in Individuals, Groups and Organizations (pp. 132-1560. San Francisco, CA: Jossey Bass.

Eccles, S., Devis-Rozental, C., \& Mayer, M. (2016). Developing Socio-Emotional Intelligence in First Year Students. American Journal of Educational Research.

Elias, M.J., Zins, J.E., Weissberg, R.P., Frey, K.S., Greenberg, M.T., Haynes, N.M., Kessler, R., Schwab-Stone, M.E. \& Shriver, T.P. (1997). Promoting Social and Emotional Learning: Guidelines for Educators. Alexandria, VA: ASCD.

Friedman, A. \& Philips, M. (2004). Continuing professional development: Developing a vision. Journal of Education and Work, 17, 361-376. http://dx.doi.org/10.1080/1363908042000267432 
Fullan, M.G. (1993). Why teachers must become change agents. Educational leadership, 50(6).

Geertz, C. (1973). Thick descriptions: Towards an interpretive theory of culture. In C. Geertz (ed.), The Interpretation of Cultures: Selected Assays (pp.3-30). New York, NY: Basic Books.

Goleman, D. (1995). Emotional Intelligence. New York, NY: Bantam Books.

Grant, A.M. (2007). Enhancing coaching skills and emotional intelligence through training. Industrial and Commercial Training Journal, 39 (5), 257-266.

Grant, A. M., Passmore, J., Cavanagh, M. J., \& Parker, H. M. (2010). 4 The State of Play in Coaching Today: A Comprehensive Review of the Field. International review of industrial and organizational psychology, 25(1), 125-167.

Griffiths, K. (2005). Personal coaching: A model for effective learning. Journal of Learning Design, 1(2), pp. 55-65.

Guskey, T.R. (2002). Professional development and teacher change. Teachers and Teaching: Theory and Practice, 8 (3/4), 381-391. DOI: 10.3102/0034654311413609

Hargreaves, A. (2001). Learning to Change: Teaching Beyond Subjects and Standards. San Francisco, CA: Jossey-Bass.

Hargreaves, A. (2005). Educational change takes ages: Life, career and generational factors in teachers' emotional responses to educational change. Teaching and Teacher Education, 21 (8), 967-983.

Haskett, R. (2003). Emotional intelligence and teaching success in higher education. Doctoral dissertation. Indiana University.

Hattie, J. (2015). What Doesn't Work in Education: The Politics of Distraction. London: Pearson.

Hughes, M. \& Terrell, J.B. (2009). Coaching with emotional and social effectiveness. In M. Hughes, H.L. Thompson \& J.B. Terrell (eds.), Handbook for Developing Emotional and Social Intelligence: Best Practice, Case studies, and Strategies (pp.3-20). San Francisco, CA: Pfeiffer.

Haynes, N.M. (2007). The Comer School Development Program: A pioneering approach to improving social, emotional and academic competence. In R. Bar-On, J.G Maree \& M.J. Elias (eds.), Educating People to Be Emotionally Intelligent (pp. 95108). Westport, CT: Praeger.

Herpertz, S., Schütz, A. \& Nezlek, J. (2016) . Enhancing emotion perception, a fundamental component of emotional intelligence: Using multiple-group SEM to evaluate a training program. Personality and Individual Differences, 95, 11-19. https://doi.org/10.1016/j.paid.2016.02.015

Jennings, P.A. \& Greenberg, M.T. (2009). The pro-social classroom: Teacher social and emotional competence in relation to student and classroom outcomes. Review of Educational Research, 79 (1), 491-525. DOI: 10.3102/0034654308325

Jennings, S. \& Palmer, B.R. (2007). Enhancing sales performance through emotional intelligence development. Organizations and People, 14 (2), 55-61.

Katz, R. (2005). Coaching for Life. Tel-Aviv: Opus (Translated from the Hebrew).

Kaufhold, J.A. and Johnson, L.R. (2005). The analysis of the emotional intelligence skills and potential problem areas of elementary educators. Education, 125 (4), 615-626.

Kyriacou, C. (1998). Essential Teaching Skills (2nd Ed.). Cheltenham: Nelson Thornes.

Lasky, S. (2005). A sociocultural approach to understanding teacher identity, agency and professional vulnerability in a context of secondary school reform. Teaching and Teacher Education, 21(8), 899-916. https:// doi.org/10.1016/j.tate.2005.06.003

Lennick, D. (2007). Emotional competence development and the bottom line: Lessons from American Express financial advisors. In R. Bar-On, J. G. Maree \& M.J. Elias 
(eds.), Educating People to Be Emotionally Intelligent (199-210). Westport, CT: Praeger.

McCown, K., Jensen, A.L. \& Freedman J. (2007). The Self-Science approach to socialemotional learning. In R. Bar-On, J.G. Maree \& M.J. Elias (eds.), Educating People to Be Emotionally Intelligent (109-122). Westport, CT: Praeger.

Maree, J.G. \& Mokhuane, Q.E. (2007). First steps in developing a community-based teacher training program designed to educate children to be emotionally intelligent. In R. Bar-On, J.G. Maree \& M.J. Elias (eds.), Educating People to Be Emotionally Intelligent (139-154). Westport, CT: Praeger.

McKee, A., Johnston, F., Mwelwa, E. \& Rotondo, S. (2009). Resonant leadership for results: An emotional and social intelligence program for change in South Africa and Cambodia. In M. Hughes, H.L. Thompson and J.B. Terrell (eds.). Handbook for Developing Emotional and Social Intelligence: Best Practices, Case Studies, and Strategies. San Francisco, CA: Pfeiffer, pp. 49-72

McKinsey Report on Education. (2007). How the Worlds' Best Performing Schools Came Out on Top. Retrieved from http://www.mckinsey.com/App_Media/Reports/SSO/Worlds_School_Syste ms_Final.pdf

Muijs, D. (2006). Measuring teacher effectiveness: Some methodological reflections. Educational Research and Evaluation: An International Journal on Theory and Practice, 12 (1), 53-74.

Myint, A. A. \& Aung, A. A. (2016). The relationship between emotional intelligence and job performance of Myanmar school teachers. Journal of Teacher Education, 1(1), $1-16$.

Neale, S., Spencer-Arnell, L. \& Wilson, L. (2009). Emotional Intelligence Coaching: Improving Performance for Leaders, Coaches and the Individual. London: Kogan Page.

Nias, J. (1996). Thinking about feeling: The emotion in teaching. Cambridge Journal of Education, 26 (3), 293-306.

Orme, G. \& Cannon, K. (2000). Everything you wanted to know about implementing an emotional intelligence programme: 1 - Getting started. Competency and Emotional Intelligence Quarterly, 8(1), 19-24.

Palomera, R., Fernandez-Berrocal, P. \& Brackett, M.A. (2008). Emotional intelligence as a basic competency in pre-service teacher training: Some evidence. Electronic Journal of Research in Educational Psychology, 15( 6), 437- 454. http://repositorio.ual.es/bitstream/handle/10835/539/Art_15_276_eng.pdf?se quence $=1$

Parker, J.D.A., Stone, H.E. \& Wood, L.M. (2009).Emotional intelligence, leadership, and the school administrator. In M. Hughes, H.L. Thompson \& J.B. Terrel (eds.), Handbook for Developing Emotional and Social Intelligence: Best Practices, Case Studies, and Strategies (379-398). San Francisco, CA: Pfeiffer.

Perry, C. \& Ball, I. (2007). Dealing constructively with negatively evaluated emotional situations: The key to understanding the different reactions of teachers with high and low levels of emotional intelligence. Social Psychology of Education, 10 (4), 443-454. DOI 10.1007/s11218-007-9025-z

Peterson, D.B. (1996). Executive coaching at work: The art of one-on-one change. Consulting Psychology Journal: Practice and Research, 48(2), 78-86.

Richardson, V. (1998). How teachers change: What will lead to change that most benefits student learning? National Centre for the Study of Adult Learning and Literacy (NCSALL), 2(c). Retrieved from http://ncsall.net/index.html@id=395.html 
Rivers, S.E. \& Brackett, M.A. (2011). Achieving standards in the English language arts (and more) using the Ruler Approach to social emotional learning. Reading and Writing Quarterly, 27, 75-100. DOI: 10.1080/10573569.2011.532715

Robertson, J.M. (2004). Coaching leaders: The path to improvement. Presented at the Biennial Conference of the New Zealand Educational Administration and Leadership Society, 7-10. January, Dunedin, New Zealand.

Salovey, P. and Mayer, J.D. (1990). Emotional Intelligence. Integration, Cognition and Personality, 9 (3), 185-211.

Slaski, M. \& Cartwright, S. (2003). Emotional intelligence training and its implications for stress, health and performance. Stress and Health, 19 (4), 233-239.

Strauss, A. and Corbin, J. (1990). Basics of Qualitative Research: Grounded Theory Procedures and Techniques. Newbury Park, CA: Sage.

Stronge, J.H. (2007). Qualities of Effective Teachers (2nd Ed.). Alexandria, VA: ASCD.

Stronge, J.H., Tucker, P.D. \& Hindman, J.L. (2004). Handbook for Qualities of Effective Teachers. Alexandria, VA: ASCD.

Sutton, R.E. \& Wheatley, K.F. (2003). Teachers' emotions and teaching: A review of the literature and directions for future research. Educational Psychology Review, 15 (4), 327-358.

Training \& Development Agency for Schools (TDA), (2008). Continuing Professional Development Guidance (CPD). London, TDA.

Ulloa, M., Evans, I. M., \& Jones, L. C. (2016). The effects of emotional awareness training on teachers' ability to manage the emotions of preschool children: An experimental study. Escritos de psicología, 9(1), 1-14. DOI: 10.5231/psy.writ.2015.1711

van Uden, J. M., Ritzen, H., \& Pieters, J. M. (2013). I think I can engage my students. Teachers' perceptions of student engagement and their beliefs about being a teacher. Teaching and Teacher Education, 32, 43-54. DOI: 10.1016/j.tate.2013.08.005

Waajid, B., Garner, P. W. \& Owen, J.E. (2013). Infusing Social Emotional Learning into the Teacher Education Curriculum. The international Journal of emotional Education. 5 (2), 31-48.

Weare, K. \& Gray, G. (2003). What Works in Developing Children's Emotional and Social Competence and Well-Being? Department for Education and Skills, Research Report No. 456, Notingham: DfES.

Weber, R.P. (1990). Basic Content Analysis (2nd Ed.). Newbury Park, CA: Sage.

White, D. (2006). Coaching Leaders: Guiding People Who Guide Others. San Francisco, CA: Jossey-Bass

Zins, J.E., Elias, M.J. \& Greenberg, M.T. (2007). School practices to build social-emotional competence as the foundation of academic and life success. In R. Bar-On, J.G. Maree \& M.J. Elias (eds.), Educating People to Be Emotionally Intelligent, pp.79-94. Westport, CT: Praeger.

Zins, J.E., Weissberg, R.P., Wang, M.C. \& Walberg, H.J. (2004). Building Academic Success on Social and Emotional Learning: What Does the Research Say? New York, NY: Teachers College Press. 